\title{
Philoctetes' Sister: Feminist Literary Criticism and the New Misogyny
}

\author{
NANCY K. MiLleR
}

Feminist critics have a complicated relationship to home. It's a place you might want to visit, but you wouldn't want to live there ... anymore. The comforts of home (nostalgias about) are bad for politics; they create false intimacies and support hierarchies of domestic violence. In the university, departments can get to seem like home; in some institutions one talks of a home department, the way we had "homerooms" in high school. For some time now I've been without a true departmental home. The last time I had an official one it was the French Department at Columbia (I "belonged" to the "family" by virtue of my degree but was never allowed to grow up there). When I finally left the French Department for the Women's Studies Program at Barnard, I took the first steps toward institutional homelessness. A program, especially an interdisciplinary one, is not a department and is defined by the fact that no one is meant to live there. By the time I joined an English department at CUNY seven years later, my sense of an (intra) institutional home had been radically eroded: add to this the fact that at the Graduate Center I also became a member of the French and Comparative Literature programs (except that at the Graduate Center those programs function as departments), as well as the Women's Studies faculty (which is a program), rotating my teaching every semester,

An earlier version of this essay appeared in my book Getting Personal: Feminist Occasions and Other Autobiographical Acts (New York: Routledge, 1991), ${ }^{\circ} 1991$ by Nancy K. Miller; used here in revised form by permission.

When I wrote the essay that follows for the Conference on Narrative Literature organized by Susan Stanford Friedman and held at Madison, Wisconsin, in April 1989, I was thinking primarily of misogyny practiced by masculinist critics (which did not preclude the possibility of the occasional female honorary man). Writing today, I would need to redefine the field to include egregious examples of "feminist misogyny," building on Susan Gubar's provocative analysis, "Feminist Misogyny: Mary Wollstonecraft and the Paradox of 'It Takes One to Know One,' " forthcoming in Feminism beside Itself, ed. Diane Elam and Robyn Wiegman (New York: Routledge). A great deal of feminism in the 905 seems bent on an internal critique indistinguishable in its tactics and vulgarity from the standard masculinist model of rational violence. It is difficult to understand what interests are served by these frontal assaults, if not those of the very misogynists whose discriminatory views engendered the articulation of feminist positions in the first place. 
and you start to get the picture. Where did I belong? In an attempt to check my nomadism (I was also expected to change offices every semester), I finally persuaded the powers that be to give me an office... in the English Program segment of the corridor of the Grace Building on the fortieth floor. In the tiny office I share (but it has a window!) I have often wondered where I live. (I know I'm in New York because I have a view of the Hudson River.) Once a week I travel to Lehman College in the Bronx, where the office I share has a view of the reservoir; that doesn't feel much like a home either. At CUNY the motto should be: "We are all adjuncts" —or almost; some of us, it's true, travel with tenure.

In this postmodern moment the multiplicity of my sites of teaching seems almost, as they say, de rigueur. I cross departmental borders on a regular basis and have therefore come to wonder whether we ought to be making such a fuss about the permeability of boundaries. In each displacement I'm still bringing whatever it is that I have to offer: as a feminist, as a reader in two languages, as a cultural critic. What does it mean to be a comparatist and a feminist? The answer I have in mind reminds me of the punch line of the old joke that goes something like this: A man crosses the border between France and Italy (or Mexico and the United States) on a daily basis. He does this for years on his bicycle. Finally, the customs official says, "Look, I know you've been taking something across the border. Today's my last day on the job, I'm retiring. Just tell me: What are you smuggling?'" And the man tells him: bicycles.

\section{Did Philoctetes Have a Sister?}

In "School-Time," the second book of The Mill on the Floss, Maggie Tulliver visits her brother Tom, who has been sent away to school for what their father calls "a good eddication: an eddication as'll be a bread to him. ${ }^{\prime 1}$ What this means to Mr. Tulliver emerges in a conversation he has with Mr. Riley, a gentleman (and auctioneer) who has impressed Tulliver with his learning, and who is advising him in the proper choice of school. To Riley's question about Tom's intelligence, Tulliver replies:

Well, he isn't not to say stupid-he's got a notion $o^{\prime}$ things out $o^{\prime}$ door, an' a sort $\mathrm{o}^{\prime}$ commonsense, as he' $\mathrm{d}$ lay hold $\mathrm{o}^{\prime}$ things by the right handle.

'George Eliot, The Mill on the Floss (New York: Penguin, 1979), 56; subsequent references are cited in the text. 
But he's slow with his tongue, you see, and he reads but poorly, and can't abide the books, and spells all wrong, they tell me, an' as shy as can be wi' strangers, an' you never hear him say 'cute things like the little wench. Now, what I want is, to send him to a school where they'll make him a bit nimble with his tongue and his pen, and make a smart chap of him. I want my son to be even wi' these fellows as have got the start $\mathrm{o}^{\prime}$ me with having better schooling. (69)

On the first day of Maggie's visit, Tom proves as clumsy laying hold of things by the right handle as with his tongue (moving his lips as he reads his Latin lessons). Trying to impress his sister with his prowess by impersonating the Duke of Wellington, he drops the sword he has been waving about-heroically, he hopes-on his foot and faints dead away from the pain. Tom's accident, which he briefly fears will leave him lame, brings him unexpectedly (and as briefly) closer to his more intellectually gifted schoolmate Philip Wakem. Philip, who reads Greek with pleasure - this impresses Maggie and baffles Tom-has in the past entertained Tom with what Tom calls "fighting stories," and on this occasion he tells Tom and Maggie the story of Philoctetes, "a man who had a very bad wound in his foot, and cried out so dreadfully with the pain, that his friends could bear with him no longer, but put him ashore on a desert island, with nothing but some wonderful poisoned arrows to kill animals with for food" (258-59). Maggie and Tom have different reactions to Philip's narrative about the lame man: Tom claims that he didn't roar out with pain; Maggie feels that it is permissible to cry out when injured, but her response to the story is finally less a reaction to the accident itself than to its consequences, the lame man's abandonment on the island. "She wanted to know," Eliot's narrator writes, "if Philoctetes had a sister, and why she didn't go with him on the desert island and take care of him" (259). (I will return to Maggie's question.)

In "The Wound and the Bow," Edmund Wilson reflects on the legend of Philoctetes as dramatized by Sophocles. Wilson begins his reflection by observing that the play is "far from being his most popular," and the "myth itself ... not ... one of those which have excited the modern imagination." The Philoctetes, Wilson argues early in the essay, "assigns itself ... to a category even more special and less generally appealing [than that of Le misanthrope, to which he compares its psychological conflict] through the fact ... that the conflict is not even allowed to take place between a man and a woman." Commenting on the limited "imprint of the play on literature since the Renaissance," perhaps because of its exclusive focus on the relations between men, Wilson cites the example of a "French dramatist of the seventeenth century, Chateau- 
brun, [who] found the subject so inconceivable that, in trying to concoct an adaptation which would be acceptable to the taste of his time... provided Philoctetes with a daughter named Sophie with whom Neoptolemus was to fall in love and thus bring the drama back to the reliable and eternal formula of Romeo and Juliet and the organizer who loves the factory-owner's daughter." ${ }^{2}$

My concern here is not to determine whether Philoctetes really had a sister, a daughter, or even a mother-though we can, I suppose, feel rather more certain about the last. Nor by my emphasis on Maggie's creation of a woman in the text am I advocating an "ethics of care" (in Carol Gilligan's terms) or a "poetics of need" (in Lawrence Lipking's). I want to suggest instead that, like the feminist critic at the end of the twentieth century, reading against the doxa of indifference and its institutional exclusions, Maggie imagines a sister for Philoctetes and inserts herself in a story otherwise notable, as Wilson points out, for being "devoid of feminine interest" in order to place herself as a subject of cultural narrative. Maggie had already bumped up against the codes of gender in her first visit to Mr. Stelling's school. She had pondered the example in her brother's Latin Grammar of the "astronomer who hated women," wondering whether "all astronomers hated women, or whether it was only this particular astronomer." She concluded without waiting for the teacher's answer: "I suppose it's all astronomers: because you know, they live up in high towers, and if the women came there, they might talk and hinder them from looking at the stars" (220). On the heels of this mournful interpretation, she had heard Mr. Stelling pronounce, to her brother's immense satisfaction, that girls had "a great deal of superficial cleverness," but that "they couldn't go far into anything. They're quick and shallow" (220-21). Maggie, whose father had earlier lamented to Mr. Riley the "topsy-turvy world" which produces "stupid lads and 'cute wenches" (68-69), and who will not be sent away to Mr. Stelling's to learn Latin or Greek, returns home after her visit, reduced to silence by the prospect of "this dreadful destiny" (221).

Feminist critics have for two decades debated the matter of the astronomers and their hatred of women, in particular and in general. Mary Jacobus, in a discussion of the politics of women's writing, has offered an especially rewarding reading of misogyny in these passages and the staging in Eliot's novel of the "question of women's access to knowledge and culture and to the power that goes with them." ${ }^{\prime 3}$ But

'Edmund Wilson, "The Wound and the Bow," in The Wound and the Bow: Seven Studies in Literature (New York: Oxford University Press, 1965), 223-24.

"Mary Jacobus, "Is There a Woman in This Text?," in Reading Woman: Essays in Feminist Criticism (New York: Columbia University Press, 1986), 68. 
let us leave the Mill and turn now instead to the misogyny of the new astronomers-the Stellings of contemporary literary life in academia. I want to look specifically at the language of their reactions to the feminist critics who have pursued in different ways the implications in literature and in culture of the "dreadful destiny" reserved for girls like Maggie Tulliver: the thwarted life and early death-to pick a fable dear to literary feminism-of Shakespeare's sister, famously imagined by Virginia Woolf.

\section{A Report from the Academy, or the New Astronomy}

In the fall of 1988 American Scholar (the organ of Phi Beta Kappa) published an essay called "Feminist Literary Criticism" (and subtitled "A Report from the Academy"). Its author, Peter Shaw, identified as "the author of the forthcoming The War against the Intellect: Episodes in the Decline of Discourse," begins his report with an epigraph from Virginia Woolf: "The greatest writers lay no stress upon sex one way or the other. The critic is not reminded as he reads them that he belongs to the masculine or feminine gender." ${ }^{4}$ The choice of epigraph is important, for it appropriates-at the threshold of a hostile review of feminist criticism - the signature of feminist criticism's "foremother," who appears here to authorize the dismissal of one of literary feminism's central questions: the relation of gender to the reading and writing of literature and criticism. Through Woolf the critic both separates himself from the challenge of feminist criticism-having to remember as he reads the effects of a social identity constituted in gender-and universalizes his position through his adherence to the canons: "the greatest writers."

This is not an especially original essay (it is very reminiscent in its basic moves of Denis Donoghue's 1986 attack on feminist criticism: a generic trashing, one might say), but its interest for us here resides precisely in its patronizing familiarity. "Feminist Literary Criticism"

${ }^{4}$ Peter Shaw, The War against the Intellect (Iowa City: University of Iowa Press, 1989); subsequent references are cited in the text. Although I've consulted several Woolf scholars, I have been unable to locate this quotation, and have begun to wonder whether it has been misremembered, just as the critic converts my phrase "women's writing" to "gender difference." Is this epigraph a transformation of: "It is fatal for any one who writes to think of their sex" (A Room of One's Own [New York: Harcourt, Brace, and World, 1967], 108)? Woolf, moreover, tends to use the word sex, not gender, to mark constructed gendered identities.

${ }^{5}$ The Denis Donoghue piece, "A Criticism of One's Own," originally appeared in the 
marks the reincrustation of an updated misogyny-the refusal to acknowledge the epistemological and cultural constructions of sexual difference-within a certain (we're all human) mainstream. I think it's worth attending to this renewal of discursive misogyny (directed at feminists on behalf of women!) as part of a general movement of reactionary gestures within a variety of institutional contexts. ${ }^{6}$

The report begins with what its author takes to be the "most troublesome" question within feminist criticism today: "whether or not women's writing differs in some essential way from men's" (67). Like Donoghue's, this irascible humanist's difficulty with feminist criticism is intimately bound up with what he calls, placing it within quotation marks, "critical theory." "This term," he writes, "which once simply designated theorizing about literature, has of course come to refer to the range of French-derived, post-structuralist theories of which the best known is deconstruction. Feminist critics," he goes on to claim, "among others, appear to have borrowed the recherché vocabulary of post-structuralism chiefly as a handy form of certification in today's theory-ridden academy" (71). In this chronology we are now witnessing a stage three of "gender theory" which owes its particular tone to its adoption of "critical theory." He then addresses the "troublesome question" that constitutes the internal failure of this phase of feminist criticism. "The trouble came with the attempt to make a case for an essential gender difference in the act of writing. For exactly where, they were forced to ask, can gender be identified as crucial in writing? Does it manifest itself in plot? In style? In setting?"' (71). (It is an intriguing fact that whenever a critic of feminism wants to criticize feminist theories or practices as being essentialist, she or he-I of course include

New Republic and was reprinted in Men in Feminism, where I commented on its rhetorical strategies. See Men in Feminism, ed. Alice Jardine and Paul Smith (New York: Routledge, 1987), 146-52, 137-45.

"Other examples that come to mind include Richard Levin's "reading" of feminist Shakespeareans in the pages of PMLA ("Feminist Thematics and Shakespearean Tragedy," PMLA 103 [March 1988]: 125-38) and Jeffrey Hart's "Wimmin against Literature," National Review, September 30, 1988, 432-33, which also uses Woolf-Mrs. Woolf-against the "feminist professors" and enlists the "it is fatal for anyone who writes to think of their sex" against their analyses (44). More recently we have Helen Vendler's "Feminism and Literature," which appeared in the New York Review of Books, May 30, 1990, 19-25. I should also say for the record that my own feminist criticism, in the form of the essay "Emphasis Added," comes briefly under (unfriendly) scrutiny in this overview. On the occasion of the conference at Madison, I included a discussion of those remarks, with what I hoped sounded like a certain contempt, which I enjoyed reading aloud to a sympathetic audience. It has seemed to me, however, in the time that has elapsed since that event that the emphasis I want to place in this version of the essay falls less on menothing personal-than on the more general rage against feminist theory and practice. 
female critics as well-in turn essentializes the representation by using the terms essential, essentially.)

As opposed to the feminist quest for "an essential gender difference in the act of writing" that reads self-consciously for the operations of gender in cultural narratives, the humanist defends the old values of transparency: the apprehension of an art outside the pressures of ideology. The critic in that story, a cultivated reader at home in a library of great books, needs to understand of a work only what is selfevidently there; the critic's task is to supply "a satisfactory account of the aesthetic object." The critical elaboration of this account, the argument goes, constitutes a poetics of "moral action," a practice that eschews politics: it is a reading without an agenda, enlisted in the service of art itself. Although such a poiesis is difficult, the failure to share the difficulty of a beyond politics as a goal is what shocks in the work of feminist critics. Granted, an "unintended bias" has always accompanied literary criticism; but being "inadvertently influenced by politics" is one thing; to choose "subordination to its aims and principles" is a failure of "social morality" - like "cheating at cards." "Feminist critics ... have repudiated the morality of the aesthetic.... Until and unless feminist criticism commits itself to aesthetic value, one can predict, it will continue to turn in on itself, repudiating one stage after another of necessarily inadequate theory" (85). To the extent that feminist criticism is by definition an ethical project, and as such bound to a "morality of the aesthetic" which includes aesthetics' ethical contexts (the very sort that Woolf, precisely, understood as integral to a humane apprehension of art), it is difficult to imagine that we stand a chance with our humanist.

But exactly which politics, one might well wonder, have undermined feminist criticism? "Mainstream liberal feminist criticism," we read, "has allowed itself to be taken intellectually hostage by French structuralist biologism, ... Marxism, white and black lesbianism, and other radical forms of expression" (86). The remaining mainstream, liberal, heterosexual (presumably), bourgeois (white and black, one assumes)

\footnotetext{
${ }^{7}$ On this matter we may well consult the great moralist Trollope, who offers these austere views of the practice in The Duke's Children (the conversation is between the Duke and his younger son, Gerald, about his acquaintance, "a so-called gentleman"):

"He should know black from white. It is considered terrible to cheat at cards."

"There was nothing of that, sir."

"The man who plays and cheats has fallen low indeed."

"I understand that, sir."
} 
feminists-who have escaped hijacking by these dangerous others, and who are still reading the essay-should renounce their alliances with "political radicals" and rededicate themselves to the arduous apprenticeship of aesthetic value: art for the sake of art. ${ }^{8}$ But would that go far enough?

The heart of the matter comes in the final paragraph of the essay, where the promise of the epigraph is fulfilled.

The one broad avenue to participation in the life of the culture always thought to have been open to women-literature's noble republic of the spirit-is in one way or another effectively denied women by feminist criticism. Yet it was through literature that Mary Ann Evans, writing as George Eliot, could confront her world unfettered by any limitations that might be thought to attach to her as a woman. Through literature Emily Dickinson and Willa Cather were free to write poems and stories in which the "I" who speaks is male rather than female, thereby claiming their privilege to speak for any kind of human being their imaginations were capable of grasping. ... In a field where women's excellence is incontestable, feminist literary critics, starting out in the conviction that women writers had long suffered at the hands of male critics, have ended up fostering an image of women at least as insulting as any that they set out to protest. (87)

In the celebration of a universal subjectivity in art, the old (we hoped, moribund) tenets of lit. crit.-bashing are resuscitated by an attack on feminist critics cast as a defense of women and culture. ${ }^{9}$ Through literature, and more specifically through the use of the male pseudonym and male personae, women writers have been able to liberate themselves and attain a whole human experience.

What is "new" here-but of course misogyny is never really newis the protection of women from their feminist sisters. By their insistence on the work of gender in culture (Did Philoctetes have a sister? Mary Ann Evans wondered), on exposing the exclusions of women from the "broad avenue to participation in the life of the culture" (George Eliot freed Mary Ann Evans from being read "as a woman"), feminist critics have denied women the subjectivity of their fictional

${ }^{8}$ I owe the image of your "average feminist critic [as the] helpless victim of dangerous lesbian hijackers" to Maaike Meijer, who wonders, sardonically, about Shaw's contradictory defense of "the moral need for an artistic space, where no such thing as morality exists-the ethics of the unethical." Unpublished comments at the conference "Double Trouble," Utrecht, Holland, May 1990.

'Donoghue writes in the same spirit: "Indeed, feminist criticism seems at its present stage to me to be a libel upon women" ("A Criticism of One's Own," 151). 
"I's" (writing "as a man"). They have also, it seems, denied male critics their fantasy monopoly on human identity.

\section{"Reader, My Story Ends with Freedom"}

In the broadside delivered against feminist criticism as a political poetics, the argument assumes that the reading of literary texts can and should be abstracted from the reminder of gender, and that writing about them should perform the same forgetting. In the presence of great writing, the reader ideally forgets both the author's sex and his own. I don't know whether the critic of feminist literary politics would go on to make the same argument about black literary feminism and the role played by race in cultural production: the common humanity expressed and transcended through art in a severance from the social. In the attack on feminist criticism I am about to describe, however, the argument connecting gender to race within cultural enactments is made explicitly; and to put that politics of abstraction into bolder relief, I want to begin with a critical reading that, like the text it illuminates, forgets neither gender nor race.

In Self-Discovery and Authority in Afro-American Narrative, Valerie Smith argues that the slave narrators of the nineteenth century, like the "protagonist-narrators of certain twentieth-century novels by AfroAmerican writers affirm and legitimize psychological autonomy by telling the stories of their own lives." Her central point relies on the "paradox" "that by fictionalizing one's life, one bestows a quality of authenticity on it ... that the processes of plot construction, characterization, and designation of beginnings and endings-in short the process of authorship-provide the narrators with a measure of authority unknown to them in either real or fictional life." In this way, Smith maintains, "narrators not only grant themselves significance and figurative power over their superordinates, but in their manipulation of received literary conventions they also engage with and challenge the dominant ideology."10

In her discussion of Harriet Jacobs's autobiographical narrative, Incidents in the Life of a Slave Girl, Smith emphasizes the fundamental problem of form that confronts the author of a slave narrative. "When Jacobs asserts that her narrative is no fiction, that her adventures may seem incredible but are nevertheless true... that only experience can

\footnotetext{
${ }^{10}$ Valerie Smith, Self-Discovery and Authority in Afro-American Narrative (Cambridge: Harvard University Press, 1987), 2; subsequent references are cited in the text.
} 
reveal the abomination of slavery, she underscores the inability of her form adequately to capture her experience" (40). Jacobs, Smith observes,

invokes a plot initiated by Richardson's Pamela, and recapitulated in nineteenth-century American sentimental novels, in which a persistent male of elevated social rank seeks to seduce a woman of a lower class. Through her resistance and piety, she educates her would-be seducer into an awareness of his own depravity and his capacity for true, honorable love. In the manner of Pamela's Mr. B, the reformed villain rewards the heroine's virtue by marrying her. (41)

The familiar rhetoric of this plot both enables and disables an effective representation of slavery in narrative. On the one hand, the effusive apostrophes to the reader, euphemistic language, and silence about sexual detail create a common reading ground with the white female readers Jacobs must address and persuade; and Jacobs is writing both to "engender additional abolitionist support" and move women readers in the North to action. But at the same time, Smith observes, the insistence on the structural similarity also trivializes the violence that inheres in slave experience. Pamela, after all, can escape to her parents' home, and have her "virtue rewarded" by marrying her master, and "elevating her and their progeny to his position" (37). By definition, or rather by the logic of slavery, the master does not marry his slave, and her posterity becomes another increment to his property.

But as Smith shows, the tension between similarity and difference can produce a gain for narrative. When the reader arrives at the end of the autobiography and is addressed by the apostrophe "Reader, my story ends with freedom; not in the usual way, with marriage," Jacobs "calls attention to the space between the traditional happy ending of the novel of domestic sentiment and the ending of her story" (42). Unlike Jane Eyre, moreover, whose jubilant preclosural address to the reader- "Reader, I married him" - has posed problems for feminist readers, and who, like Pamela, could marry her master and bear his child legitimately, Linda Brent (the pseudonym of Jacob's first-person narrator) ends her story still questing for a "home": "The dream of my life is not yet realized. I do not sit with my children in a home of my own. I still long for a hearthstone of my own." Jacobs's text is constructed, we might say, in the gaps produced by that difference: the irreducible distance between slave reality and sentimental narrative, both of which finally remain authorized by patriarchy. 
My account of Smith's argument has emphasized her analysis of the dramatic ways in which narrative commonalities allow us to take the measure of difference in readers: when, for instance, the white female reader who stops over "Reader, my story ends with freedom; not in the usual way, with marriage" perceives the difference race makesthat freedom for one who doesn't own herself comes from being sold, "sold at last" — she is reminded of both her gender and her race. Should she as a critic seek to forget this?

In the summer of 1988 Valerie Smith and I participated in a number of events at the School of Criticism and Theory. Smith gave a lecture, "Gender and Afro-Americanist Literary Theory and Criticism," in which she addressed-among other things-the question of oppositional discourses and their relation to institutional contexts and constraints; I presented "Dreaming, Dancing, and the Changing Locations of Feminist Criticism." In his reply to the arguments of this piece, the director of the school, Michael Riffaterre, a well-known semiotician, laid out before an audience of students and colleagues what he took to be the assumptions of my work as a feminist critic. The critique, while necessarily dependent on the existence of my person as a pre-text, identifies itself for the most part as being addressed to what is labeled (by him) in capital letters Feminist Criticism (hereafter FC, by me). In what follows I hope to show how the two takes on FC-the humanist's outcry and the semiotician's lament, which one might not have supposed to interpenetrate-in fact relay each other on a continuum of reaction: the discourse here of universal literary value, which in turn rejoins the earlier call for a "morality of the aesthetic."

Before reviewing the critique, I need to say a word about this mixed mode of autobiography and cultural analysis I call narrative criticism. Although, as I have just suggested, I figure in the story primarily as a convenient metonymy of FC (its Mary Beton, just as the reader may like to imagine the first critic as Woolf's Mr. A., whose phallic "I" casts a long shadow over the pages of his prose, and the second as the angry Professor Von X in A Room of One's Own), it is also the case that my account emerges from an institutional performance in which I coincided personally, as it were, with my representativity. My object in returning now to the critical material of that occasion, however, beyond the selfjustification that comes with the territory of autobiography, ${ }^{11}$ is to il-

\footnotetext{
${ }^{11}$ In his response to the version of this chapter that I read at the Conference on Narrative Literature, D. A. Miller commented, with an edge of misgiving, on the degree to which its writing "finds its source and support in self-vindication ... shielding the author's very body against (real, remembered, imagined) attack." Perhaps.
} 
luminate the network of theoretical assumptions about literature and literary criticism at the heart of the new astronomy.

The critic moves quickly to his main point, which is to challenge the "insularity of Feminist Criticism." He finds it "strange" that "the same people who would campaign against any form of male-enforced segregation or discrimination against women, or against any discrimination, and rightly so, should become segregationists in Feminist Criticism and discriminate against men as readers." Feminist Critics, he complains, "are not content to define [our] difference, [we] are othering male critics... and excommunicating their interpretations." (Feminist critics are addressed through me as "you." I have changed that here to "we.") Explicitly or not, he maintains, we "posit that, being male, they cannot possibly understand or properly read a text that has been written by a woman for women." And, he concludes in the next sentence, "it is obvious that the premises of today's Black Criticism imply the same kind of exclusion."12

What is one to make of the scenario that has male critics bodily prevented from reading women's writing and white critics from reading black writing? What feminist beadle has barred their access to the library, banned their books, banished their hermeneutics? Looking out across the cartography of our institutions, one can only wonder: Who left whom on the island? And yet we need now to take a harder look at the language of othering which posits the exclusions and the relations between them. How are Feminist and Black Critics (or, translated into the consecrated phrase of affirmative action, "women and minorities") alike and different? What is going on when feminists are accused of "segregation" in their attitudes toward male critics-a word intimately associated with the history of racism in this country? (More typically in antifeminist rhetoric, feminists are accused of separatism, which is in turn of course a code word for lesbianism.)

The collapsing of distinctions in order to maximize their threat echoes the language of the most reactionary forces at work in the academy today. (It is an emblem of recent political culture.) An example is Jon Wiener's account in the Nation of a conference titled "Reclaiming the Academy: Responses to the Radicalization of the University," calling for a "'renewed assertiveness' against feminism, ethnic studies and literary theory." The reporter quotes a spokesperson, Alan Kors, an intellectual historian from the University of Pennsylvania: "The immediate threat to academic freedom comes from antiharassment poli-

${ }^{12}$ I am quoting here from the text of Michael Riffaterre's public remarks, which at my request he communicated to me in written form at the close of the meeting. 
cies, racial awareness programs and the enshrinement of 'diversity' as a value for the university." 13

But let us return to the insularity of FC:

Our duty as critics ... is to explain and communicate. Furthermore, the only item that needs explaining to others and needs vicarious experiencing by them through the text is precisely the difference, be it gender, or class, or race. Why then, why start by saying that you cannot even succeed unless you own that difference by birthright? ... Suppose we considered that metalinguistic features depending on gender, race, and class are unlikely ever to be erased, and that criticism by a native from the gender, race, or class under study might facilitate understanding. ... Even if we were to concede that, the insularity of what I should call native criticism (rather than personal, or gender, or race criticism) would still ignore the very nature of the literary phenomenon, namely that it transcends time, place, and borders.

What would it mean to read Incidents in the Life of a Slave Girl as though its project transcended time, place, and borders? Smith's poetics of slave narrative, as we have just seen, focuses on the tensions (and contradictions) between the representational demands of the slave narrative and narrative structures of self-fictionalization. But this attention to formal literary conventions also includes a critical awareness of "the political and economic context in which the texts have been produced." To ignore "the broad context in which [the texts] were written," Smith maintains, "invites misreading and denies their relation to the conditions and the sense of urgency that contributed to their very existence" (6). Does this mean that to read Jacob's text as a slave narrative-a female-authored account of that historical experience-is to perform a "native criticism" that by definition "ignore[s] the very nature of the literary phenomenon"? To cite Smith one last time: "The critical work, no less than the artistic, bears the imprint of the conditions under which it was produced and articulates the writer's relation to culture" (7). This belief in cultural context, I would argue, is no more "insular"-you have to be black (a black woman) to "properly read" a black-authored tex $\mathrm{t}^{14}$ - than the article of faith that circumscribes the text in order to

${ }^{13}$ Nation, December 12, 1988, 644. In a letter in the February 6, 1989, issue of the Nation (146), Kors complains about being misquoted.

${ }^{14}$ Michael Awkward provides an evenhanded discussion of this complicated issuedo you have to be black to read a black-authored text, and so on-through the work of Clifford Geertz, notably the essay "From the Native's Point of View," in his article "Race, Gender, and the Politics of Reading," Black American Literature Forum 22 (Spring 1988): 5-27. It is worth observing, as a participant at the conference on narrative pointed out in 
seal its borders. In the case of Incidents in the Life of a Slave Girl, for example, if as a critic-black or white, male or female-you failed to explain the inscription of race and gender in the text's structures of address, your "account of the aesthetic object" (to invoke the terms of the argument rehearsed earlier) would by the same token overlook the "metalinguistic features" that give the text its generic specificity.

In other words, rather than adopting a discourse of the monument that rigidly opposes an inside ("the literary phenomenon") to an outside ("time, place, and borders"), we need precisely a revisionary "morality of the aesthetic" that would produce a reading capable of interpreting, for instance, the marks of race and gender in the text as intrinsic to literariness itself. This would be another way of understanding the ethical project of feminist aesthetics. The reading model according to which the critic radically divides literature from culture-as though we could ever be sure where to draw the lineseems condemned to the very insularity it seeks to locate outside its operations: to reproducing the politics of its location. Geographically this means not noticing, for instance, that continents are only very large islands.

\section{Lemnos and the Politics of Insularity}

Having arrived at this point in my narrative, I find myself wanting to tie up all the loose ends with a novelistic fabrication, a turn or twist of the plot, bringing us all, it all-Maggie, Philoctetes, the conservative backlash - to satisfying, if not sublime closure: marriage or freedom or Troy or home. Reader, I ... Reader, my story ends with ... But how does it end? How do I want it to end?

We could return, for instance, to the matter left hanging in Maggie's question about Philoctetes' sister and her conviction that she would have cared for the wounded man left on the island, and have that figure for us a reflection about gendered plots, and specifically about the ways in which universal narratives-what Gayatri Spivak calls "regulative psychobiography"15_construct and are constructed by social and political agendas.

We could also observe that these othered male critics would prefer

the question period, that in the first case FC. is seen as foreign-influenced by France, using recherché words; here, native. In both FC is marked off as different from a transparent, essentialized self-identity: Art, Literature, The Critic, The Text, and so on.

${ }^{15}$ Gayatri Spivak, "The Political Economy of Women as Seen by a Literary Critic," in Coming to Terms, ed. Elizabeth Weed (New York: Routledge, 1989), 227. 
for feminists to be more like women (like Maggie) and look after their wounded heroes.

We might ponder the current academic debates about the status and effects of oppositional discourses; these are joined issues.

And we might even wonder whether there isn't a way in which, like Philoctetes, feminists have come to love their island and to look with great suspicion on the call (when it is not a demand) for them to return to the fatherland, for this is, I think, what the accusations of insularity, segregation, separatism, and feminist misogyny come down to.

Philoctetes, we recall, was abandoned by Odysseus and their comrades in arms almost ten years before the play begins. They left Philoctetes on the island of Lemnos because they couldn't take the smell of his stinking foot and the howls of pain his wound produced. Now, having learned from a prophecy that Troy can be captured only by Philoctetes' bow-a bow given to him by Heracles-Odysseus and Neoptolemus have come back to get the bow and the man. Philoctetes takes a dim view of rejoining the war at the behest of the man who had so cruelly abandoned him to fend for himself on this deserted island; even though the return to Troy includes the promise of a cure, Philoctetes would rather suffer his pain and find solace on those terms. The crux of the play involves the persuasion of Philoctetes, a decision to leave the island for Troy that is accomplished only through the intervention of a god coming out of the machine: the appearance onstage of Heracles, who commands Philoctetes to pick up his bow and go back to the war.

The Philoctetes has attracted a great deal of critical attention and competing interpretations. ${ }^{16}$ Following Carola Greengard's emphasis on the play's political dimensions I will recast, for a postmodern feminist theater, the fable of the man on the island as a drama of political positioning.

Suppose, then, that we imagine the lonely Philoctetes on the island multiplied as a collective of feminist critics. They have been put on the island because they have been ruining life on the mainland; they keep complaining about their wound, and that odor di femmina has been overpowering. ${ }^{17}$ After the feminist critics have spent a decade of life in

${ }^{16} \mathrm{~A}$ good summary can be found in P. E. Easterling's "Philoctetes and Modern Criticism," Illinois Classical Studies 3 (1978): 27-39.

${ }^{17}$ The Lemnian setting, it should be mentioned, "was traditionally associated [both] with the Cybele cult and with myths that center on murderous conflict between men and women or exclusive occupancy of the island by women." Indeed, the "most famous myth is that of the Lemnian women killing all the men on the island in revenge for desertion." It is also possible, following this connection, to interpret, as some scholars have, the "offensive odor of the mythic Lemnian women" as transposed "in Philoctetes's foul 
their women's studies community-we can just borrow some pages from Monique Wittig's Guérillères to fill in the narrative here-the men (their former colleagues) decide they need them back. They've heard rumors, oracles, that the feminists have unique knowledge that can help them deal with their students: enrollments are down, almost all the graduate students are female and are demanding to read women's and minority writing (even the men want to be in feminism); their publishers are telling them to include women in their articles and their books. They send an emissary-not one of the old guard, of course, but a younger representative (like Neoptolemus), one of the graduate students perhaps, or an assistant professor who does Theory.

Should the women return to save the institution? What faith can they have that promises will be kept? Even if they can forgive past wrongs, can they expect no future ones? It has been painful in the wilderness, but also rewarding. They have forged new identities on the island which challenge the hierarchical conventions of the polis; these might not survive the return to the old war, the rules of a tarnished, virile heroism. In Sophocles' play, we should remember, it takes a god coming out of a machine to force Philoctetes' hand and bring him with his bow to Troy.

After two decades of FC, feminists, black and white, as well as other oppositional groups find themselves both marginalized (put on the island) for reasons of state and accused of insularity, of separatism, even "terrorism;"18 othered and accused of othering; excluded and taxed with being exclusionary. As we confront the fin de siècle, of which much is being made, the question of the islands and their "natives" becomes more and not less acute.

You will by now have perceived at least one crucial difference between my drama and the legend of the man on the island. The difference is not sexual. ${ }^{19}$ It is one of numbers: unlike Philoctetes, we are not alone on our islands. Odysseus, even supported by the gods and their prophecies, can less easily, in this postcolonial moment, make us an offer we can't refuse. We can look from our island not only to the main but peripherally at the other island people and propose what we would now call coalition politics, famously defined by Bernice Reagon as the antithesis of home: "You don't go into coalition because you just like it.

wound." Carola Greengard, Theatre in Crisis: Sophocles' Reconstruction of Genre and Politics in Philoctetes (Amsterdam: Adolph M. Hakkert, 1987), 47-48.

${ }^{18} \mathrm{~K}$. K. Ruthven, Feminist Literary Studies: An Introduction (Cambridge: Cambridge University Press, 1984), 10.

${ }^{19}$ But, like Philoctetes', our difference-according to the legend-is marked in our bodies. 
The only reason you would consider trying to team up with somebody who could possibly kill you, is because that's the only way you can figure you can stay alive." 20 In that spirit we could chant some old radical cries of solidarity like "We are all Lemnians," hoping enough collective historical memory is left to make sense of it. But to end on that note would be to offer a solution that is already nostalgic.

Philoctetes, you recall, had no way to leave Lemnos on his own. As feminist critics we have acquired the freedom to move between the island and the mainland: we can leave and return, and we do. ${ }^{21}$ Indeed, the definition of feminist difference has historically been bound up with the movement between identities and locations, with the negotiations between scenes of power. Nonetheless, for us, as for Philoctetes, the stakes of negotiation remain high and require vigilance, since we do not yet set the terms of the discussion. Nor is it clear that the gods are on our side.

Toward the end of "The Wound and the Bow," Wilson reads the Philoctetes allegorically: "The victim of a malodorous disease which renders him abhorrent to society and periodically degrades him and makes him helpless is also the master of a superhuman art which everybody has to respect and which the normal man finds he needs" (240). He then identifies the "more general and fundamental idea" of the play to be "the conception of superior strength as inseparable from disability" (235), but more specifically moves on to the "modern" reading that he comes to through Gide's reworking of the legend in his play-"that genius and disease, like strength and mutilation, may be inextricably bound up together." Gide, he remarks, "like the hero of the play, stood at an angle to the morality of society and defended [his] position with stubbornness" (237).

It is finally, I think, these intertwined figures of the wound and the bow, and a stubbornness born of that doubled difference, that we might most usefully retain for now. For through their somatic insistence they

\footnotetext{
${ }^{20}$ Bernice Johnson Reagon, "Coalition Politics: Turning the Century," in Home Girls: A Black Feminist Anthology, ed. Barbara Smith (New York: Kitchen Table Press, 1984), 35657 .

${ }^{21}$ In April 1990 I gave a version of this paper at the Third Annual Conference on Women's Studies at Dubrovnik. As luck would have it, from my room at the hotel I could see the island of Lokrum, a large, beautiful island, thick with trees, which we went to visit one afternoon on a boat ride. After contemplating the island for several days, and making the trip there, I realized I had not sufficiently figured in the ambivalence of perspective that double siting creates: the politics of oscillation. (This could also point to another fable about feminism, the referent, and movements of political liberation, but I will have to leave that for another time.) I thank Myriam Diaz-Diacoretz and Nada Popovich for including me in this event.
} 
mark off the grounds and the position of a necessary resistance to the warriors- "the normal man" - of a very old world.

I wrote "Philoctetes' Sister" in the spring of 1989 following an attack on me-representatively-as a feminist critic the summer before. It was, of course, also an attack on me personally, to which I at the moment did not, could not, reply. The violence left me mute, like Philomela. When two years later I published the essay in Getting Personal, a book in which I make the case for an autobiographical criticism, I still was not ready to acknowledge in print the degree to which my troping of insularity was a coded response to the experience of public humiliation. I decided to play the George Eliot card and rise above it.

It seems to me now that this choice left a couple of important things unsaid. The person who trashed me/Feminist Criticism (a cyborg of sorts) had been my dissertation director (another kind of monster) many years earlier. The audience before whom he trashed me was made up, at least in part, of students I was then teaching. In the Charlotte Brontë repertoire this resembled the standard curriculum of sadistic pedagogies: the nightmare of confused identities. And as in a nightmare, the dreamers were paralyzed by the horror of the show. We didn't, as one of my students kept saying afterwards, know what to do. Clearly I didn't either. Not everyone was horrified by the show. Some were entertained, some disappointed: Why didn't I "destroy" him in turn? Oedipal modalities notwithstanding, I couldn't have. But in the aftermath of the Clarence Thomas-Anita Hill performances, I have come to think that dignity - which may be too grand a name for my inhibition, not to say fear-is a mistake, even if it has some selfprotective value for the moment.

There is nothing new about misogyny in literature or in our social lives. What may be new is an institutionalization of its terms in the best places. The question is: What are we going to do about it? 